\title{
Ticks and rickettsiae from wildlife in Belize, Central America
}

\author{
Marcos G. Lopes ${ }^{1}$, Joares May Junior ${ }^{2,3}$, Rebecca J Foster ${ }^{2,4}$, Bart J Harmsen ${ }^{2,4}$, Emma Sanchez ${ }^{2,4}$, Thiago F. Martins ${ }^{1}$, \\ Howard Quigley ${ }^{2}$, Arlei Marcili, ${ }^{1,5}$ and Marcelo B. Labruna ${ }^{1 *}$
}

\begin{abstract}
Background: The agents of spotted fevers in Latin America are Rickettsia rickettsii, R. parkeri, Rickettsia sp. strain Atlantic rainforest, and $R$. massiliae. In Continental Central America, $R$. rickettsii remains the only known pathogenic tick-borne rickettsia. In the present study, ticks were collected from wild mammals in natural areas of Belize. Besides providing new data of ticks from Belize, we investigated rickettsial infection in some of these ticks. Our results provide ticks harboring rickettsial agents for the first time in Central America.

Methods: Between 2010 and 2015, wild mammals were lived-trapped in the tropical broadleaf moist forests of central and southern Belize. Ticks were collected from the animals and identified to species by morphological and molecular analysis (DNA sequence of the tick mitochondrial 16S RNA gene). Some of the ticks were tested for rickettsial infection by molecular methods (DNA sequences of the rickettsial $g / t A$ and ompA genes).

Results: A total of 84 ticks were collected from 8 individual hosts, as follows: Amblyomma pacae from 3 Cuniculus paca; Amblyomma ovale and Amblyomma coelebs from a Nasua narica; A. ovale from an Eira Barbara; A. ovale, Amblyomma cf. oblongoguttatum, and Ixodes affinis from a Puma concolor; and A. ovale, A. coelebs, A. cf. oblongoguttatum, and I. affinis from two Panthera onca. Three rickettsial agents were detected: Rickettsia amblyommii in A. pacae, Rickettsia sp. strain Atlantic rainforest in A. ovale, and Rickettsia sp. endosymbiont in Ixodes affinis.

Conclusions: The present study provides unprecedented records of ticks harboring rickettsial agents in the New World. An emerging rickettsial pathogen of South America, Rickettsia sp. strain Atlantic rainforest, is reported for the first time in Central America. Besides expanding the distribution of 3 rickettsial agents in Central America, our results highlight the possible occurrence of Rickettsia sp. strain Atlantic rainforest-caused spotted fever human cases in Belize, since its possible vector, A. ovale, is recognized as one of the most important human-biting ticks in the Neotropical region.
\end{abstract}

Keywords: Amblyomma ovale, Amblyomma pacae, Amblyomma oblongoguttatum, Ixodes affinis, Rickettsia, Wild animals, Central America

\section{Background}

Belize is a tropical country occupying an area of only $22,800 \mathrm{~km}^{2},<5 \%$ of continental Central America. Despite its relatively small land, Belize is recognized by its high biodiversity, especially wildlife. Among 900 tick species of the world, nearly 200 are found in the Neotropical Zoogeographic region $[1,2]$. The tick fauna of

\footnotetext{
*Correspondence: labruna@usp.br

'Department of Preventive Veterinary medicine and animal Health, Faculty of Veterinary Medicine, University of São Paulo, São Paulo, SP 05508-270, Brazil Full list of author information is available at the end of the article
}

Belize is currently composed of 18 species, distributed in the genera Amblyomma (13 species), Ixodes (2), Rhipicephalus (2), and Dermacentor (1) [1,3].

Tick-borne rickettsiae are bacterial agents of the genus Rickettsia that cause emerging and re-emerging zoonoses worldwide [4]. Recent reviews on the occurrence of Rickettsia species in Latin America indicated that only 3 tick-borne Rickettsia species occur in Central American main land, in contrast to at least 9 rickettsial agents infecting ticks in South America [4, 5]. In fact, until 2009, Rickettsia rickettsii, the agent of Rocky Mountain 
spotted fever, was the only tick-borne rickettsia known to occur in Central America, with reports from Panama and Costa Rica [5]. In these two countries, $R$. rickettsii has been associated with three tick species, Amblyomma mixtum (reported as Amblyomma cajennense), Dermacentor nitens, and Haemaphysalis leporispalustris [6-8]. Since 2009, two more tick-borne Rickettsia species have been reported in continental Central America: Rickettsia bellii infecting Amblyomma sabanerae from El Salvador and Costa Rica [9, 10] and Amblyomma rotundatum from Panama [11]; and Rickettsia amblyommii infecting A. mixtum (reported as A. cajennense) from Panama, Costa Rica, and Honduras [8, 12, 13] and Amblyomma longirostre from Costa Rica and Honduras [10, 13]. Additionally, at least three uncultured rickettsial agents have been reported in Central America, namely Rickettsia sp. strain IbR-CRC in Ixodes boliviensis from Costa Rica [14], Rickettsia sp. endosymbiont (strain Barva) in Ixodes minor from Costa Rica [10], and Rickettsia sp. strain Colombianensi in Amblyomma dissimile from Honduras [13].

The current scenario of tick-borne rickettsiae in Latin America is still modest, compared to Europe, where more than 20 tick-borne agents have been reported [4]. Moreover, whereas nearly 10 tick-borne rickettsiae are agents of human illness (generally known as spotted fevers) in Europe, only 4 tick-borne rickettsiae are known to cause spotted fevers in humans in Latin America [4]. The agents of spotted fevers in Latin America are R. rickettsii, R. parkeri, Rickettsia sp. strain Atlantic rainforest, and $R$. massiliae [4]. In Continental Central America, $R$. rickettsii has remained as the only known pathogenic tickborne rickettsia.

In the present study, ticks were collected from wild mammals in natural areas of Belize. Besides providing new data of ticks from Belize, we investigated rickettsial infection in some of these ticks. Our results provide ticks harboring rickettsial agents for the first time in Central America.

\section{Methods}

Between 2010 and 2015, wild mammals were livedtrapped in the tropical broadleaf moist forests of central and southern Belize, as part of a study of wildlife movement. Ticks were collected from the animals and stored in plastic tubes containing $92 \%$ ethanol. In the laboratory, ticks were identified to species through morphological examination following specific identification keys for Amblyomma species [15, 16], and for Ixodes species $[17,18]$. Morphological identification was confirmed by molecular analysis. For this purpose, representative specimens of each tick species were submitted to DNA extraction using the guanidine isothiocyanate phenol technique [19] and tested by a PCR assay targeting a portion of the tick mitochondrial 16S rRNA gene, as previously described [20]. Amplicons were purified with ExoSap (USB, Cleveland, Ohio, USA) and DNAsequenced in an ABI automated sequencer (Applied Biosystems/Thermo Fisher Scientific, model ABI 3500 Genetic Analyzer, Foster City, California, USA) with the same primers used for PCR. The sequences obtained were submitted to blast analyses (www.ncbi.nlm.nih.gov/ blast) to infer the closest similarities available in GenBank.

The mitochondrial 16S rRNA partial sequences of Ixodes ticks collected in the present study were aligned with corresponding 16S rRNA sequences of different Ixodes species available in GenBank, which included mostly those species belonging to the Ixodes ricinus species complex, as recently reported [21]. The sequence of Ixodes uriae was used as outgroup. Phylogenetic trees were inferred by the maximum parsimony methods and were performed with PAUP 4.0b10 software [22] with 1000 replicates of random-addition taxa and tree bisection and reconnection branch swapping; all positions were equally weighed.

Tick DNA samples were screened for rickettsial infection by a PCR protocol using primers CS-78 and CS323, targeting a 401-bp fragment of the rickettsial citrate synthase gene $(g l t \mathrm{~A})$ [23], which is relatively conserved among Rickettsia species [24]. Samples yielding visible PCR products by this PCR were further tested with primers Rr190.70p and Rr190.701n, targeting a 631-bp fragment of the rickettsial $190-\mathrm{kDa}$ outer membrane protein gene (ompA) [25]. In each set of reactions, negative control tubes containing water and a positive control tube containing DNA of Rickettsia sp. strain NOD were included. Amplicons were purified and DNAsequenced as described above, and then submitted to blast analyses.

Ethical approval. This work was authorized by the Government of Belize's Forest Department; research permits are $\mathrm{CD} / 60 / 3 / 09(18), \mathrm{CD} / 60 / 3 / 10(44), \mathrm{CD} / 60 / 3 /$ 12(21), $\mathrm{CD} / 60 / 3 / 15$.

\section{Results}

A total of 84 ticks were collected from 8 individual hosts, comprising 5 different tick species from 5 host species (Table 1). Four of the five tick species belonged to the genus Amblyomma, and were morphologically identified as Amblyomma ovale, Amblyomma coelebs, Amblyomma pacae, and Amblyomma cf. oblongoguttatum. This later species is provisionally treated with "cf." because its external morphology presented slight differences to A. oblongoguttatum from Brazil (type locality of A. oblongoguttatum), which will be presented in detail in another manuscript, still in progress (M.B.L., unpublished data). 
Table 1 Ticks (M: males, F: females, N: nymph, L: larva) collected from wild hosts in Belize and the rickettsial detection in part of the ticks

\begin{tabular}{|c|c|c|c|c|c|c|}
\hline \multicolumn{4}{|c|}{ Vertebrate hosts } & \multirow[t]{2}{*}{ Tick species: No. per stage } & \multicolumn{2}{|l|}{ Rickettsial detection in ticks } \\
\hline No. & Order: Family & Species & Locality $^{a}$ & & No. positive/No. tested (\%) & Rickettsia species \\
\hline 1 & Rodentia: Cuniculidae & Cuniculus paca & A & Amblyomma pacae: $1 \mathrm{M}$ & & \\
\hline 2 & & C. paca & A & A. pacae: $1 \mathrm{M}$ & & \\
\hline 3 & & C. paca & A & A. pacae: $2 \mathrm{M}, 1 \mathrm{~F}$ & $1 / 1(100)$ & R. amblyommii \\
\hline \multirow[t]{2}{*}{4} & Carnivora: Procyonidae & Nasua narica & A & Amblyomma ovale: $1 \mathrm{M}, 1 \mathrm{~F}$ & $0 / 1(0)$ & \\
\hline & & & & Amblyomma coelebs: $1 \mathrm{~N}$ & & \\
\hline 5 & Carnivora: Mustelidae & Eira barbara & A & A. ovale: $2 \mathrm{~F}$ & $0 / 1(0)$ & \\
\hline \multirow[t]{3}{*}{6} & Carnivora: Felidae & Puma concolor & B & A. ovale: $6 \mathrm{M}$ & $2 / 4(50)$ & Rickettsia sp..$^{b}$ \\
\hline & & & & Amblyomma cf. oblongoguttatum: 1 M, 6 F & $0 / 3(0)$ & \\
\hline & & & & Ixodes affinis: $4 \mathrm{M}, 6 \mathrm{~F}$ & $4 / 4(100)$ & Rickettsia sp. $^{c}$ \\
\hline \multirow[t]{4}{*}{7} & & Panthera onca & B & A. ovale: $6 \mathrm{M}$ & $1 / 3(33.3)$ & Rickettsia sp. ${ }^{b}$ \\
\hline & & & & A. coelebs: $1 \mathrm{~L}$ & $0 / 1(0)$ & \\
\hline & & & & A. cf. oblongoguttatum: $3 \mathrm{M}, 2 \mathrm{~F}, 1 \mathrm{~L}$ & $0 / 2(0)$ & \\
\hline & & & & Ixodes affinis: $3 \mathrm{M}, 12 \mathrm{~F}$ & $6 / 7(85.7)$ & Rickettsia sp..$^{c}$ \\
\hline \multirow[t]{4}{*}{8} & & Panthera onca & B & A. ovale: $2 \mathrm{M}$ & & \\
\hline & & & & A. cf. oblongoguttatum: $2 \mathrm{~F}$ & & \\
\hline & & & & A. coelebs: $1 \mathrm{~N}$ & & \\
\hline & & & & Ixodes affinis: $5 \mathrm{M}, 13 \mathrm{~F}$ & 8/9 (88.9) & 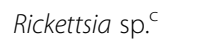 \\
\hline
\end{tabular}

${ }^{a}$ A: Private lands, Cayo district; B: Cockscomb Basin Wildlife Sanctuary, Stann Creek district

${ }^{\mathrm{b}}$ strain Atlantic rainforest

crickettsia endosymbiont of Ixodes affinis

Morphological identifications were corroborated by molecular analysis, as the mitochondrial 16S rRNA gene partial sequences of $A$. ovale, A. coelebs, and A. pacae matched $\geq 99 \%$ similarity to conspecific sequences available in GenBank, while the sequences of $A$. cf. oblongoguttatum matched closest $(\approx 92 \%$ similarity $)$ to a sequence of $A$. oblongoguttatum from Brazil (Table 2). Two Amblyomma larvae from the same individual host were molecularly identified as $A$. coelebs and $A$. cf. oblongoguttatum (Tables 1, 2). A total of 43 tick specimens belonged to the genus Ixodes, and were morphologically identified as Ixodes affinis. Through molecular analyses, the $16 \mathrm{~S}$ rRNA partial sequences of 18 Ixodes specimens generated 7 different haplotypes, which were 97-99 \% closest to corresponding sequences of I. affinis from southeastern United States (Table 2). In the phylogenetic analysis (Fig. 1), the 7 haplotypes of I. affinis from Belize formed a clade with 5 haplotypes of I. affinis from the United States [GenBank: U95879, AF549834, KT037645, KT037645] and Colombia [GenBank: AF549861], under moderate bootstrap support (79 \%).

A total of 36 tick specimens were tested for rickettsiae through PCR. Three rickettsial agents were detected: Rickettsia amblyommii in A. pacae, Rickettsia sp. strain Atlantic rainforest in A. ovale, and Rickettsia sp. endosymbiont of Ixodes affinis (Table 1). Both the gltA and the ompA partial sequences of $R$. amblyommii were
$100 \%$ identical to corresponding sequences in GenBank [JF694089, CP012420, respectively]. Both the gltA and the ompA partial sequences of Rickettsia sp. strain Atlantic rainforest were $100 \%$ identical to corresponding sequences in GenBank [GQ855235, KM116015, respectively].

The gltA partial sequence of Rickettsia sp. endosymbiont of Ixodes affinis was $99.7 \%$ (336/337-bp) identical to Rickettsia sp. IbR-CRC [GenBank: KJ507211], previously detected in I. boliviensis from Costa Rica, and $99.4 \%$ (348/350-bp) identical to both Rickettsia monancensis, previously detected in Ixodes ricinus from Europe [GenBank: LN794217], and Rickettsia sp. Barva, previously detected in I. minor from Costa Rica [GenBank: KF702332]. The ompA partial sequence of Rickettsia sp. endosymbiont of Ixodes affinis was 99.8 \% (586/587-bp) identical to Rickettsia sp. Barva, previously detected in $I$. minor from Costa Rica [GenBank: KF702334], $99.6 \%$ (503/505-bp) identical to Rickettsia sp. IbR-CRC, previously detected in I. boliviensis from Costa Rica [GenBank: KJ507218], and $98.9 \%$ (556/562-bp) and $99.0 \%$ (536/541-bp) identical to the rickettsial endosymbionts of Ixodes scapularis [GenBank: XM002401667] and Ixodes pacificus [GenBank: GU047354], respectively.

Voucher tick specimens collected in the present study have been deposited at the tick collection "Coleção Nacional de Carrapatos" (CNC) under the accession 
Table 2 Ticks processed by molecular analysis for determination of their $16 \mathrm{~S}$ rRNA gene partial sequences, and their closest similarities in GenBank

\begin{tabular}{|c|c|c|c|c|}
\hline Tick species & Specimens $^{a}$ & Haplotype code & Host No. in Table 1 & Closest similarity in GenBank for the $16 \mathrm{~S}$ rRNA gene \\
\hline \multirow[t]{4}{*}{ Amblyomma ovale } & $4 \mathrm{M}, 1 \mathrm{~F}$ & Ao1 & $4,6,7$ & 99.5 \% A. ovale Brazil (KR605467) \\
\hline & $1 \mathrm{M}$ & Ao2 & 6 & $99.0 \%$ A. ovale Brazil (KR605467) \\
\hline & $1 F$ & Ao3 & 5 & $99.3 \%$ A. ovale Brazil (KR605467) \\
\hline & $1 \mathrm{M}$ & Ao4 & 7 & $99.3 \%$ A. ovale Brazil (KR605467) \\
\hline A. pacae & $1 \mathrm{M}$ & Ap1 & 3 & 99.7 \% A. pacae Brazil (JX141384) \\
\hline A. coelebs & $1 \mathrm{~L}$ & $A c 1$ & 7 & $99.0 \%$ A. coelebs Argentina (KM519936) \\
\hline \multirow[t]{2}{*}{ A. cf. oblongoguttatum } & $2 F, 1 L$ & Acfol & 6,7 & $92.2 \%$ A. oblongoguttatum Brazil (FJ424407) \\
\hline & $1 \mathrm{~F}$ & Acfo2 & 6 & 91.9 \% A. oblongoguttatum Brazil (FJ424407) \\
\hline \multirow[t]{7}{*}{ Ixodes affinis } & $1 \mathrm{M}$ & la1 & 7 & $97.3 \%$ I. affinis USA (KT037643) \\
\hline & $1 \mathrm{M}, 9 \mathrm{~F}$ & la2 & $6,7,8$ & $99.8 \%$ I. affinis USA (KT037645) \\
\hline & $2 F$ & la3 & 7,8 & $98.8 \%$ I. affinis USA (KT037648) \\
\hline & $1 \mathrm{M}$ & la4 & 8 & $99.3 \%$ I. affinis USA (KT037645) \\
\hline & $1 F$ & la5 & 8 & $99.3 \%$ I. affinis USA (KT037645) \\
\hline & $1 \mathrm{~F}$ & la6 & 8 & $99.5 \%$ I. affinis USA (KT037645) \\
\hline & $2 \mathrm{M}$ & $1 \mathrm{a} 7$ & 8 & $99.5 \%$ I. affinis USA (KT037645) \\
\hline
\end{tabular}

${ }^{\mathrm{a}} \mathrm{M}$ male, $\mathrm{F}$ female, $\mathrm{N}$ nymph, L larva

numbers CNC-3159 to CNC-3166. GenBank nucleotide sequence accession numbers for the partial sequences generated in the present study are KU001155 KU001169 for the 16S rRNA gene of A. ovale, A. pacae, A. coelebs, A. cf. oblongoguttatum, and I. affinis; KU001170, KU001173 for the gltA and ompA genes of R. amblyommii; KU001171, KU001174 for the gltA and ompA genes of Rickettsia sp. strain Atlantic rainforest; and KU001172, KU001175 for the gltA and ompA genes of Rickettsia endosymbiont of I. affinis.

\section{Discussion}

The tick species found in the present study have been previously reported in Belize [26]. Our results are in agreement with previous studies, which indicated that A. pacae is a natural parasite of C. paca [27], and that $A$. ovale and $I$. affinis are natural parasites of Carnivora hosts in the Neotropical region [28, 29]. Amblyomma coelebs is primarily associated with tapirs, Tapirus spp. [30]. In fact, Tapirus bairdii is known to occur in the area where this tick was collected in the present study (data not shown). While the parasitism of immature stages of A. coelebs on $P$. onca has been previously reported [28], we provide the first report of $A$. coelebs nymph on $N$. narica. Furthermore, our findings of $A$. cf. oblongoguttatum on $P$. concolor and $P$. onca are in agreement with previous reports for $A$. oblongoguttatum infesting wild felids in Central America [29], and South America [27, 28]. However, at this moment, we are not confident that the taxon $A$. oblongoguttatum represents the same tick species in these two continents, based on slightly morphological differences (data not shown) and molecular analyses (Table 2). Because the type locality of $A$. oblongoguttatum is in Brazil [31], we are referring to the Belizean specimens as $A$. cf. oblongoguttatum.

Three (33.3\%) out of 9 A. ovale ticks were found to harbor the pathogen Rickettsia sp. strain Atlantic rainforest. This rickettsial agent was recently demonstrated to cause spotted fever in humans in Brazil $[32,33]$, where A. ovale was incriminated as a possible vector [34]. Until the present study, the occurrence of Rickettsia sp. strain Atlantic rainforest was restricted to Brazil, Colombia, and Argentina [4, 35, 36]. Thus, our results expand the distribution of this pathogen to Central America, where it must be considered a potential agent of human spotted fever. While previous studies showed that Rickettsia sp. strain Atlantic rainforest is phylogenetically related to $R$. parkeri, $R$. africae, and $R$. sibirica [32, 33, 35], the definitive taxonomic status of this pathogen still needs to be established.

We provide the first record of $R$. amblyommii in the tick $A$. pacae. This rickettsial agent has a broad distribution in the New World, infecting a variety of Amblyomma species in the United States, Honduras, Costa Rica, Panama, French Guyana, Paraguay, Argentina, and Brazil [8, 10, 12, 13, 23, 37-40]. Currently, $R$. amblyommii is considered to be a potential 


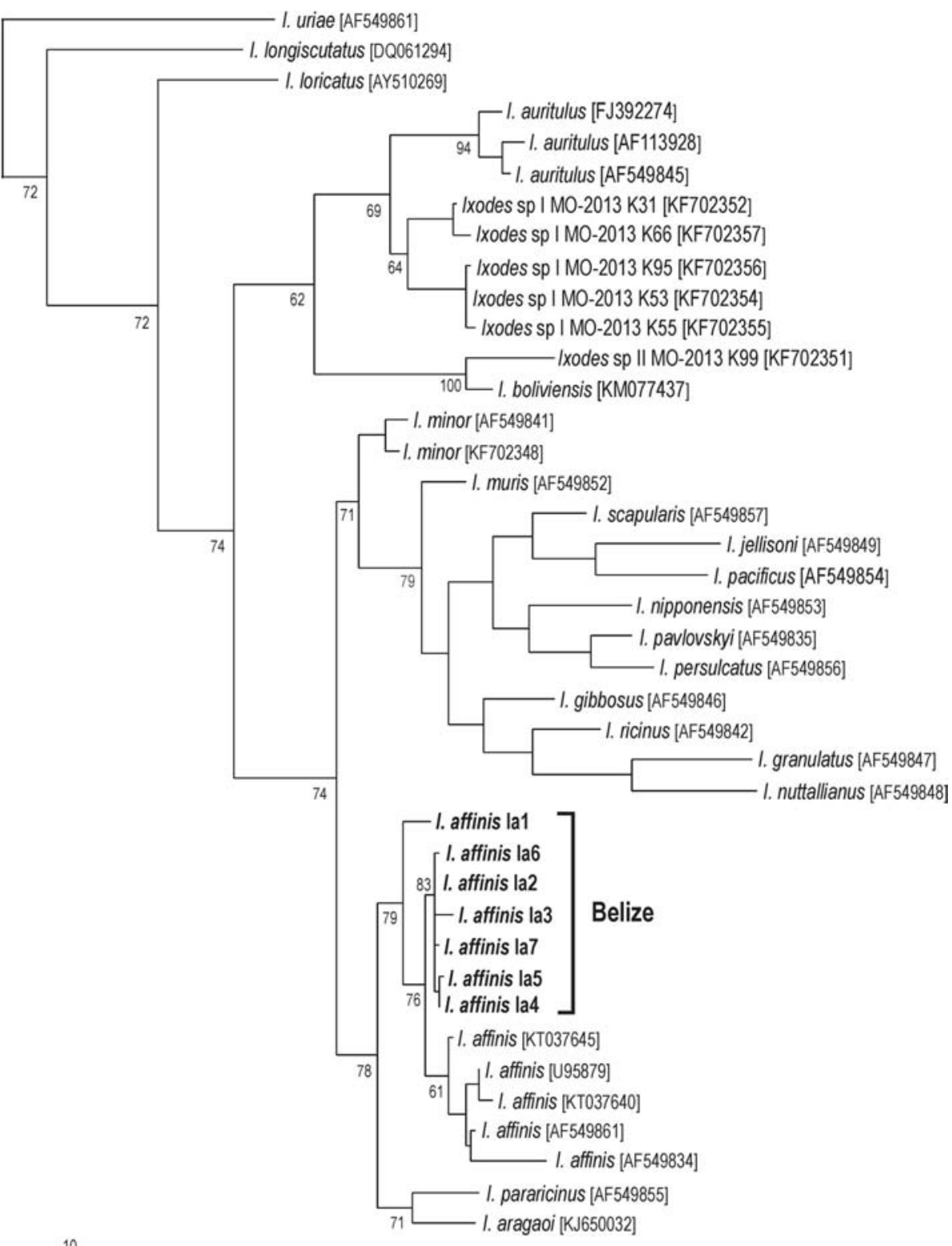

Fig. 1 Maximum parsimony (MP) phylogenetic tree of 16S rDNA partial sequences of Ixodes affinis from Belize and other tick species of the genus Ixodes. The Ixodes uriae corresponding sequence was used as outgroup. Numbers at nodes are support values derived from bootstrap (1000 replicates). Numbers in brackets are GenBank accession numbers

human pathogen, since there have been serological evidence of human infection by this agent in the United States [41, 42].

Most of the I. affinis ticks of the present study were shown to harbor a rickettsial agent. This agent was considered to be an endosymbiont, based on previous studies on closely related Ixodes species (e.g., I. scapularis, I. pacificus, I. ricinus, I. boliviensis), which were also infected by genetically close-related rickettsial endosymbionts, usually under high infection rates [14, 43]. Further studies on isolation and deeper molecular characterization are needed to elucidate the taxonomic status of the rickettsial endosymbionts of Ixodes species from Latin America.

\section{Conclusions}

The present study provides unprecedented records of ticks harboring rickettsial agents in the New World. An emerging rickettsial pathogen in South America, Rickettsia sp. strain Atlantic rainforest, is reported for the first time in Central America. Besides expanding the distribution of 3 rickettsial agents in Central America, our 
results highlight the possible occurrence of Rickettsia sp. strain Atlantic rainforest-caused spotted fever human cases in Belize, since its possible vector, A. ovale, is recognized as one of the most important human-biting ticks in the Neotropical region [27, 44].

\section{Competing interests}

The authors declare that they have no competing interests.

\section{Authors' contributions}

MGL, TFM and AM conducted lab experiments, processed the data, and revised the manuscript. JMJ, RJF, BJH, ES and $\mathrm{HQ}$ performed field study and drafted the manuscript. MBL contributed to data analysis and interpretation, and wrote the manuscript. All authors read and approved the final manuscript

\section{Acknowledgments}

This work was supported by Fundação de Amparo a Pesquisa do Estado de São Paulo (FAPESP) and Coordenação de Aperfeiçoamento de Pessoal de Nível Superior (CAPES), Brazil. Field-work was funded by the UK Darwin Initiative and Panthera.

\section{Author details}

${ }^{1}$ Department of Preventive Veterinary medicine and animal Health, Faculty of Veterinary Medicine, University of São Paulo, São Paulo, SP 05508-270, Brazil.

${ }^{2}$ Panthera, 8 West, 40th street, 18th Floor, New York, NY 10018, USA.

${ }^{3}$ Universidade do Sul de Santa Catarina, Av. José Acácio Moreira, 787, Bairro Dehon, Caixa Postal 370, CEP 88704-900 Tubarão, SC, Brazil. ${ }^{4}$ Environmental Research Institute, University of Belize, UB preschool Grounds, Price Centre Road, PO box 340, Belmopan, Belize. ${ }^{5}$ Universidade de Santo Amaro, R. Prof. Enéas de Siqueira Neto, 340, CEP 04829-300 São Paulo, SP, Brazil.

\section{Received: 17 November 2015 Accepted: 28 January 2016}

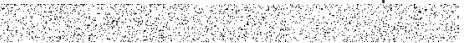

\section{References}

1. Guglielmone AA, Estrada-Pena A, Keirans JE, Robbins RG. Ticks (Acari: Ixodida) of the zoogeographic region. Atalanta: International Consortium on Ticks and Tick-borne Diseases (ICTTD-2); 2003.

2. Guglielmone AA, Robbins RG, Apanaskevich DA, Petney TN, Estrada-Peña A, Horak IG. The hard ticks of the world (Acari: Ixodida: Ixodidae). New York: Springer; 2014

3. Cooley RA, Kohls GM. The genus Amblyomma (Ixodidae) in the United States. J Parasitol. 1944;30:77-111.

4. Parola P, Paddock CD, Socolovschi C, et al. Update on tick-borne rickettsioses around the world: a geographic approach. Clin Microbiol Rev. 2013;26:657-702

5. Labruna MB, Mattar S, Nava S, et al. Rickettsioses in Latin America, Caribbean, Spain and Portugal. Rev MVZ Cordoba. 2011;16:2435-57.

6. Rodaniche EC. Natural infection of the tick, Amblyomma cajennense, with Rickettsia rickettsii in Panama. Am J Trop Med Hyg. 1953;2:696-9.

7. Fuentes L, Calderón A, Hun L. Isolation and identification of Rickettsia rickettsii from the rabbit tick (Haemaphysalis leporispalustris) in the Atlantic zone of Costa Rica. Am J Trop Med Hyg. 1985;34:564-7.

8. Bermúdez SE, Eremeeva ME, Karpathy $\mathrm{SE}$, et al. Detection and identification of rickettsial agents in ticks from domestic mammals in eastern Panama. J Med Entomol. 2009:46:856-61.

9. Barbieri AR, Romero L, Labruna MB. Rickettsia bellii infecting Amblyomma sabanerae ticks in El Salvador. Pathog Glob Health. 2012;106:188-9.

10. Ogrzewalska M, Literák I, Capek M, et al. Bacteria of the genus Rickettsia in ticks (Acari: Ixodidae) collected from birds in Costa Rica. Ticks Tick-Borne Dis. 2015;6:478-82.

11. Andoh M, Sakata A, Takano A, et al. Detection of Rickettsia and Ehrlichia spp. in ticks associated with exotic reptiles and amphibians imported into Japan. PLoS One. 2015;10(7), e0133700

12. Hun L, Troyo A, Taylor L, Barbieri AM, Labruna MB. First report of theisolation and molecular characterization of Rickettsia amblyommii and Rickettsia felis in Central America. Vector Borne Zoonotic Dis. 2011:11: 1395-7.
13. Novakova M, Literak I, Chevez L, Martins TF, Ogrzewalska M, Labruna MB. Rickettsial infections in ticks from reptiles, birds and humans in Honduras. Ticks Tick Borne Dis. 2015;6:737-42

14. Troyo A, Moreira-Soto A, Carranza M, Calderón-Arguedas O, Hun L, Taylor L Detection of an undescribed Rickettsia sp. in Ixodes boliviensis from Costa Rica. Ticks Tick Borne Dis. 2014:5:883-6.

15. Jones EK, Clifford CM, Keirans JE, Kohls GM. The ticks of Venezuela (Acarina: Ixodoidea) with a key to the species of Amblyomma in the Western hemisphere. Brigham Young Univ Sci Bull Biol Ser. 1972;17:1-40.

16. Martins TF, Onofrio VC, Barros-Battesti DM, Labruna MB. Nymphs of the genus Amblyomma (Acari: Ixodidae) of Brazil: descriptions, redescriptions, and identification key. Ticks Tick Borne Dis. 2010;1:75-99.

17. Cooley RA, Kohls GM. The genus Ixodes in North America. Nat Inst Health Bull. 1945;184:1-246

18. Keirans JE, Clifford CM. The genus Ixodes in the United States: a scanning electron microscope study and key to adults. J Med Entomol. 1978;2:1-149.

19. Sangioni LA, Horta MC, Vianna MCB, et al. Rickettsial infection in animals and Brazilian spotted fever endemicity. Emerg Infec Dis. 2005;11:265-70.

20. Mangold AJ, Bargues MD, Mas-Coma S. Mitochondrial $16 \mathrm{~S}$ rDNAsequences and phylogenetic relationships of species of Rhipicephalus and other tick genera among Metastriata (Acari: Ixodidae). Parasitol Res. 1998;84:478-84.

21. Barbieri AM, Venzal JM, Marcili A, Almeida AP, González EM, Labruna MB. Borrelia burgdorferi sensu lato infecting ticks of the Ixodes ricinus complex in Uruguay: first report for the southern hemisphere. Vector-Borne Zoonotic Dis. 2013;13:147-53.

22. Swofford DL. PAUP: Phylogenetic analysis using parsimony. Beta Version 4 0b10. Sunderland: Sinauer and Associates; 2002.

23. Labruna MB, Whitworth $\mathrm{T}$, Bouyer $\mathrm{DH}$, et al. Rickettsia bellii and Rickettsia amblyommii in Amblyomma ticks from the state of Rondônia, Western Amazon, Brazil. J Med Entomol. 2004:41:1073-81.

24. Roux V, Rydkina E, Eremeeva M, Rault D. Citrate Synthase gene comparison, a new tool for phylogenetic analysis and its application for the rickettsiae. Int J Syst Evol Microbiol. 1997:47:252-61.

25. Eremeeva ME, Bosserman EA, Demma $\downarrow$, Zambrano ML, Blau DM, Dasch GA. Isolation and identification of Rickettsia massiliae from Rhipicephalus sanguineus ticks collected in Arizona. Appl Environ Microbiol. 2006;72:5569-77.

26. Varma MG. Ticks (Ixodidae) of British Honduras. Trans R Soc Trop Med Hyg. 1973:67:92-102.

27. Labruna MB, Camargo LM, Terrassini FA, Ferreira F, Schumaker TTS, Camargo EP. Ticks (Acari: Ixodidae) from the state of Rondonia, western Amazon. Brazil Syst Appl Acarol. 2005;10:17-32.

28. Labruna MB, Jorge RSP, Sana DA, et al. Ticks (Acari: Ixodida) on wild carnivores in Brazil. Exp Appl Acarol. 2005;36:149-63.

29. Bermúdez SE, Esser HJ, Miranda R, Moreno RS. Wild carnivores (Mammalia) as hosts for ticks (Ixodida) in Panama. Syst Appl Acarol. 2015;20:13-9.

30. Labruna MB, Guglielmone AA. Ticks of New World tapirs. Tapir Conservation. 2009;18:21-8.

31. Robinson LE. The genus Amblyomma. Cambridge: Univ. Press; 1926

32. Spolidorio MG, Labruna MB, Mantovani E, Brandao PE, Richtzenhain $\sqcup$, Yoshinari NH. Novel spotted fever group rickettsiosis, Brazil. Emerg Infect Dis. 2010;16:521-3.

33. Silva N, Eremeeva ME, Rozental T, et al. Eschar-associated spotted fever Rickettsiosis, Bahia. Brazil Emerg Infect Dis. 2011;17:275-8.

34. Szabó MP, Nieri-Bastos FA, Spolidorio MG, Martins TF, Barbieri AM, Labruna $M B$. In vitro isolation from Amblyomma ovale (Acari: Ixodidae) and ecological aspects of the Atlantic rainforest Rickettsia, the causative agent of a novel spotted fever rickettsiosis in Brazil. Parasitology. 2013;140:719-28.

35. Londoño AF, Díaz FJ, Valbuena G, et al. Infection of Amblyomma ovale by Rickettsia sp. strain Atlantic rainforest, Colombia. Ticks Tick Borne Dis. 2014;5:672-5.

36. Monje LD, Nava S, Eberhardt AT, Correa Al, Guglielmone AA, Beldomenico PM. Molecular detection of the human pathogenic Rickettsia sp. strain Atlantic rainforest in Amblyomma dubitatum ticks from Argentina. Vector Borne Zoonotic Dis. 2015;15:167-9.

37. Labruna MB, Pacheco RC, Nava S, Brandão PE, Richtzenhain LJ, Guglielmone AA. Infection by Rickettsia bellii and Candidatus 'Rickettsiaamblyommii' in Amblyomma neumanni ticks from Argentina. Microb Ecol. 2007:54:126-33.

38. Parola P, Matsumoto K, Socolovschi C, Parzy D, Raoult D. A tick-borne rickettsia of the spotted-fever group, similar to Rickettsia amblyommii, in French Guyana. Ann Trop Med Parasitol. 2007;101:185-8. 
39. Ogrzewalska M, Literak I, Martins TF, Labruna MB. Rickettsial infections in ticks from wild birds in Paraguay. Ticks Tick Borne Dis. 2014;5:83-9.

40. Soares HS, Barbieri AR, Martins TF, et al. Ticks and rickettsial infection in the wildlife of two regions of the Brazilian Amazon. Exp Appl Acarol. 2015;65: $125-40$.

41. Apperson CS, Engber B, Nicholson WL, et al. Tick-borne diseases in North Carolina: is "Rickettsia amblyommii" a possible cause of rickettsiosis reported as Rocky Mountain spotted fever? Vector Borne Zoonotic Dis. 2008:8:597-606.

42. Vaughn MF, Delisle J, Johnson J, et al. Seroepidemiologic study of human infections with spotted fever group Rickettsiae in North Carolina. J Clin Microbiol. 2014;52:3960-6.

43. Kurtti TJ, Felsheim RF, Burkhardt NY, Oliver JD, Heu CC, Munderloh UG. Rickettsia buchneri sp. nov., a rickettsial endosymbiont of the blacklegged tick Ixodes scapularis. Int J Syst Evol Microbiol. 2015;65:965-70.

44. Guglielmone AA, Beati L, Barros-Battesti DM, et al. Ticks (Ixodidae) on humans in South America. Exp Appl Acarol. 2006:40:83-100.

Submit your next manuscript to BioMed Central and we will help you at every step:

- We accept pre-submission inquiries

- Our selector tool helps you to find the most relevant journal

- We provide round the clock customer support

- Convenient online submission

- Thorough peer review

- Inclusion in PubMed and all major indexing services

- Maximum visibility for your research

Submit your manuscript at www.biomedcentral.com/submit
Biomed Central 